УДК: 658.588.8:338.512

JEL Classification: D 290; D 240; D 61;L 59; L 69; O 39

Shitikova L.V., Tkachenko A.M., Voitenko S.V.

\title{
THEORETICAL AND METHODOLOGICAL ASPECTS OF EFFECTIVE TECHNICAL MAINTENANCE AND REPAIR OF PRODUCTION ASSETS IN ORDER TO REDUCE COSTS AND INCREASE ENTERPRISE POTENTIAL
}

\author{
Zaporizhzhia National Technical University, Zaporizhzhia
}

\begin{abstract}
The article is devoted to the actual problem of the effective maintenance organization and repair of production assets of enterprises in order to maintain their reliability and performance, while providing a lower cost of service by creating a cost-effective strategy and a systematic approach. Currently, the process of change in the industry has a larger development. The cost of maintenance of modern industrial assets is unfortunately increasing, both in absolute terms and in proportion to the overall costs. The paper informes that since the main purpose of the development of enterprises is the economic activity impact, the increase in labor productivity at constant cost reduction is achieved by updating and effective use of modern technology, technique, scientific advances in the field of effective maintenance and repair of industrial machinery and equipment. The current maintenance requirements are identified. They are: a high degree of availability and reliability; the greater degree of safety; high-quality products; environmental safety; longer life duration,; high rate of cost-effectiveness. The RCM methodology analysis demonstrates its effectiveness, due to the lower cost of equipment maintenance and working machines and due to fewer repairs, while maintaining their reliability. This result provides the costeffective creation of the effective strategy and systematic approach to determine the current maintenance program. It is proved that the maintenance aimed at ensuring reliability provides the process for performing tasks in modern operational context. When applied correctly, RCM system transforms the relations between enterprises that use it; by the material funds and human resources, exploiting these assets and ensure their maintenance. The process of planning task involves the following key elements: the definition of objectives and their quantities; the determination of the extent and boundaries; assessing the time and number of inspections required for the preliminary inspection of the equipment at each site; plan to implement the recommendations. In addition, this system also ensures quick, efficient and accurate commissioning of new production assets.
\end{abstract}

Keywords: maintenance, costs, potential, development, production assets, cost effective management, productivity, enterprise efficiency.

DOI: $10.32434 / 2415-3974-2019-9-1-130-135$

\section{Introduction}

The central issue of each enterprise in the current conditions of reforming the Ukrainian economy is the general cost management system, which incorporates modern approaches to the organization of effective maintenance, maintenance and repair of production assets of enterprises in order to maintain their reliability and productivity.

Only the application of complex economic methods can give today the necessary economic effect and bring the company to a new level of development [1, c.71]. Determining the cost of repairing equipment is a complex accounting and methodological problem. The difficulty lies in the fact that enterprises tend to produce several, and often a large number of types of repairs. In order to achieve the goals and objectives of the analysis, it is necessary to organize a retrospective, operational and prospective analysis at different stages of equipment repair. In solving cost management problems, it is expedient to use a system approach, the essence of which is that all elements of the system and all operations in it should be considered only as a whole, only in the relationship with each other [2]. 


\section{Formulation of the problem}

The urgency of research is due to the primary importance of resources available at the enterprise disposal, the need for the formation and further use of a scientific approach to their management. Modern enterprises operate in difficult dynamic conditions. This requires solving the problems associated withreducing costs by saving money for maintenance and repair, which is ensured by increased reliability of equipment operation. Now the requirements in the field of human and environmental safety, the quality of products are getting stronger, while technical problems have more and more serious consequences for society. The problem of rational use and management of resources is complex, but solving its components will create the preconditions for stabilization and further growth of the competitiveness and efficiency of enterprises. The complexity and dynamics of socio-economic processes require the development of new approaches to the use and management of resources. Therefore, the effective economic activity of the enterprise is possible only in research, determination and further active use of modern approaches to the organization of efficient maintenance and repair of production equipment of enterprises in order to maintain its reliability. The search for an economically profitable strategy and a systematic approach determines the research implementation and the relevance of the chosen topic.

\section{Analysis and research of publications}

The solution of the problem of effective management, competitiveness and sustainable development of enterprises is impossible without solving the problem of organization of effective maintenance and repair of machines and equipment of production enterprises, estimation of effective cost management indicators. Despite the significant achievements in the theory and practice of management, there are a number of problems that remain the subject of discussions and debatingof economists and practitioners. Issues related to the development of approaches to the organization of high-quality maintenance, the improvement of technology for the repair of production assets in order to reduce the cost and to increase the competitiveness of manufactured products, cause active scientific interest among specialists. Many scientific studies are devoted to search for solutions to the problem of organizing the service and maintenance of machinery and equipment, and the related problem of the cost management system inefficiency, used in both Ukrainian and all enterprises of the post-Soviet space. The analysis of modern scientific works and publications suggests that the chosen problem is highlighted by such scientists as M.V. Bolduev, V.O. Gulevich, N.V. Kalienina, M.I. Kapitsa,
A.V. Klymenko, I. Kozlov, O.B. Kolotikin, O. Krivoruchko, S.V. Kurochkina, P.M. Makarenko, V. A. Mozgo, Yu.I. Nagorny, N.A. Perevozhkikova, A.V. Starikov, M.A. Starikov, V.G. Shevchenko, G.A. Shovkun, V. Sholokhov. Due to the active interest of specialists, the problem under investigation is widely debated at present.

The purpose of the paper is to identify modern approaches to the organization of efficient maintenance and repair of machines and equipment of manufacturing enterprises in order to maintain the reliability of the equipment while providing a lower cost of service by creating a cost-effective strategy and a systematic approach for the current service program determination.

\section{Statement of the main material}

In today's environment, the organization of effective maintenance of production assets is based on the development and use of an effective strategy, which will eventually provide lower cost of production, increased competitiveness, stability of functioning and prospects for further development of the enterprise in the long run. The methodology for servicing production assets is based on the assumption that the volume of work will be carried out at the expense of fewer repairs, taking into account the potential of the machines, and the reliability of the equipment should be maintained.

It should also be noted that the costs of the equipment repairing are conditionally constant. To determine the reserves for reducing the cost of production, the costs are studied in terms of their role in the production process. At the same time costs are grouped according to the costing items. The classification of costs for costing items reveals the target affiliation of costs and their relationship with the technological process. The costingitems characterize the composition of the resources used and give an opportunity to estimate the amount of savings or over spending.

During the analysis it is estimated: the change in the amount and cost structure in the planned and actual cost of providing maintenance services; influence of deviation factors on actual expenses from planned ones.

Expenses of the enterprise are the cost of resources used in the process of the enterprise economic activity. All costs of living and materialized labor in the form of costs of raw materials, material, fuel and energy resources, depreciation of fixed assets, wages are reflected in the cost of production. Costs arise in the process of forming and using resources to achieve a certain goal. They have different directions related to the direct execution of the company's main function. Cost management is a process of purposeful cost formation by type and place, constant control of the level of expenses and 
stimulation of a decrease in their amount. It is an important function of the economic mechanism of any enterprise.

The cost management system has functional and organizational aspects. It includes the following organizational subsystems: the search and identification of factors of resource savings; valuation of resources expenses; planning of expenses according to their types; accounting and cost analysis; stimulating resource savings and reducing costs. Such subsystems are managed by the respective structural units of the enterprise.

It is known that the better the business is at the enterprise, the higher the technical equipment and the organization of production, the lower the cost of production and vice versa. In the modern period, reducing the cost of production is of great economic significance. Reducing the cost of production is the basis of lower prices, and therefore - the basis of the competitiveness of products, enterprises and industry. At the same time, the company strengthens its financial position, making it more stable. Detection and use of resources saving factors, cost reduction is mandatory for each employee of the enterprise. In accordance with organizational and technical solutions and conditions, it is necessary to develop cost standards for all types of resources: raw materials, basic and auxiliary materials, energy, labor resources.

The urgency of reducing the cost of production is increased with the growth of production volumes, requiring the use of costly methods for assessing the potential of machinery and equipment of the enterprise. In modern conditions, the growth of production depends largely on the production capacity of equipment and the performance of all functions in accordance with the requirements of users in the current working context. Equipment downtime leads to significant material and financial losses. This suggests that the failure of the equipment can and must be prevented in advance, which in turn leads to the concept of pre-inspection and preventive maintenance and repair.

At present, the process of industrial change has become even more driving force. The cost of maintenance of modern production assets, unfortunately, is growing, both in absolute terms and in proportion to total costs. In some industries, it is now the second or even the first in the current spending list. Thus, in just thirty years, maintenance has shifted from the lowest level to the top of the cost control system.

A significant increase in maintenance costs compared with other operating costs has led to an increase in maintenance planning and control systems. This greatly enhances control over maintenance and is now an integral part of the maintenance practice. In this situation, each percent reduction in the cost of equipment repairs provides an increasing amount of savings. With the restructuring of industry and its further dynamic development, this problem will be of paramount importance.

Over the past years, maintenance has changed, perhaps more than any other area of management. These changes are due to a significant increase in the number and large variety of material assets (buildings, equipment and facilities), their complication, the emergence of new methods of maintenance and operation, as well as a change in the views on what organization of maintenance should be and what its functions are.

These changes test the strength and professionalism of all industries without exception. Personnel employed in the field of maintenance have to acquire completely new ways of thinking and skills - this applies to both mechanics and management staff. At the same time, it becomes increasingly apparent that the capabilities of maintenance systems are limited, no matter how computerized they were.

The evolution of maintenance is in response to changing expectations, among which - a clearer understanding of the implications that may have malfunctions in the operation of equipment for the safety of people and the environment, as well as the awareness that the quality of products directly depends on the state of equipment, as well as the desire to achieve better equipment availability and reduce production costs. Faced with so many changes, managers around the world are looking for a new approach to the maintenance of productive assets. At the same time, it is important to avoid hasty actions and deadlines that are inherent in large projects, to find strategic systems that combine new technologies into a single integrated framework within which they can be judged competently and choose those that will be the most valuable to them and their own enterprises.

Maintenance, which is aimed at ensuring reliability, involves the process of ensuring that the tasks performed in the current operating context are met.

One of the most progressive modern systems of maintenance is the Reliability-centred Maintenance system (RCM).

With proper application, the RCM system transforms the relationships between enterprises that use it; available material funds and personnel who operate these funds and provides their maintenance. In addition, this system also ensures prompt, efficient and clear commissioning of new funds.

Considering the evolution of the maintenance system, there are several stages of development. The RCM system is rapidly becoming an important 
representative of the latest generation.

Modern maintenance requirements can be defined as:

- higher degree of readiness and reliability;

- high degree of security;

- higher quality products;

- ecological safety;

- long service life;

- high cost-efficiency ratio.

RCM can be used to create a cost-effective service strategy to address issues related to the main causes of hardware failure. This is a systematic approach for determining the current service program, consisting of economically feasible tasks that help to maintain the most important functions of the equipment. This process is directly related to preventive maintenance.

With the correct use of RCM, it contributes to a significant increase in maintenance performance, and this improvement comes very quickly. RCM facilitates improvement of organizational productivity in various directions, material and intangible. The material benefits are to increase the level of safety, environmental protection, increase the readiness and reliability of equipment, improve product quality, reduce operating and maintenance costs. Intangible benefits include a more complete understanding of the equipment operation by operators and service personnel, increasing the teamwork effectiveness and increasing morale.

The success of the RCM depends, above all, on careful planning and preparation. The planning process involves performing the following key elements:

- determination of scope and limits;

- determination of the number of goals (current status and end state);

- estimation of time, number of inspections required for pre-inspection of equipment at each site;

- plan for the implementation of recommendations (maintenance tasks, design changes, changes in operation processes).

One of the major problems is that in practice, service personnel simply can not answer all these questions on their own. This is because many questions (if not most) can only be answered by the production or operator staff. Therefore, it is necessary to organize the control over the performance of maintenance requirements with the help of small groups, which would include at least one servicer and one operator.

Maintenance tasks are recorded in appropriate planning and control systems with a large and small frequency, while the explored operational processes are included in the standard operating instructions.

\section{Conclusions}

It is proved that the main goal of the development of enterprises is the efficiency of economic activity, increase of productivity at constant decrease of expenses, which is achieved by updating and effective use of modern technologies, techniques, scientific achievements in the field of organization of effective maintenance and repair of production equipment.

The analysis of the RCM methodology shows its effectiveness, which is due to the lower cost of servicing productive assets due to a smaller number of repairs, while the reliability of equipment is maintained. This result is ensured by the creation of an economically profitable and effective strategy and a systematic approach for determining the current service program.

\section{REFERENCES}

1. Antonenko T.A. Znyzhennja zatrat - odna z priorytetnyh strategij dijal'nosti pidpryjemstv. - Zaporizhzhja: Tyzhden' nauky, 2014.

2. Mojsejenko V.I., Petrenko O.V., Chegodajev B.V. Vplyv tehnichnogo obslugovuvannja na pokaznyky RAMS [Bezvidmovnist', Gotovnist', Remontoprydatnist', Bezpeka]. Zaliznychnyj transport Ukrai'ny, 2015.

3. Vlasjuk G.V. Teoretychni aspekty upravlinnja vytratamy vyrobnyctva na pidpryjemstvah u rynkovyh umovah. - Derzhava ta regiony. Serija Ekonomika ta pidpryjemnyctvo, 2012.

4. Kryvoruchko O. Systema upravlinnja jakistju tehnichnogo obslugovuvannja I remontu avtomobiliv. - Standartyzacija, sertyfikacija, jakist', 2004.

5. Lytvyn O.O. Metodychni osnovy upravlinnja vytratamy na promyslovyh pidpryjemstvah Derzhava ta regiony. - Serija: Ekonomika ta pidpryjemnyctvo, 2011.

6. Mozgo V.A. Tehnycheskoe obsluzhyvanje oborudovanyja] Metody menedzhmenta kachestva, 2005.

7. Perevozchykova N.A. Prymenenje systemnogo podhoda $\mathrm{v}$ upravlenyy zatratamy na promyshlennyh predpryjatyjah Ukrayny. Donec'k: Donec'kyjnacional'nyj tehnichnyj universytet. Naukovi praci. Ser.: Ekonomichna. - 2004. - Vol.87.

8. Sholohov V. Tehnykavstyle «modern»: Promyshlennost' Ukrayny na chynaetvnedrjat' novejshje tehnologyy remonta. Den'gyytehnologyy, 2003.

Received 30.03.2019

Reviewer: Prof. Kolesnikov V.P. 


\section{ТЕОРЕТИКО-МЕТОДИЧНІ АСПЕКТИ ОРГАНІЗАЦІЇ ЕФЕКТИВНОГО ТЕХНІЧНОГО ОБСЛУГОВУВАННЯ ТА РЕМОНТІВ ВИРОБНИЧИХ АКТИВІВ 3 МЕТОЮ ЗНИЖЕННЯ ВИТРАТ І ПІДВИЩЕННЯ ПОТЕНЦІАЛУ ПІДПРИЕМСТВА \\ Шитікова Л.В., Ткаченко А.М., Войтенко С.В.}

Статтю присвячено актуальній проблемі організаці ефективного технічного обслуговування та ремонтів виробничих активів підприємств з метою збереження їх надійності та продуктивності, при забезпеченні більш низької вартості обслуговування за рахунок створення економічно вигідної стратегії та систематичного підходу. В даний час процес змін в промисловості набув ще більшої рушійної сили. Вартість технічного обслуговування сучасних виробничих активів, на жаль, зростає, як в абсолютному значенні, так і в пропориії до загальних витрат. В роботі доведено, що оскільки головною метою розвитку підприємств є результативність господарської діяльності то підвищення продуктивності праці при постійному зниженні витрат досягається оновленням і ефективним ви користанням сучасних технологій, техніки, наукових здобутків в галузі організації ефективного технічного обслуговування та ремонтів виробничих машин та обладнання. Визначені сучасні вимоги до технічного обслуговування: більш високий ступінь готовності та надійності; великий ступінь безпеки; більш висока якість продукції; екологічна безпека; велика тривалість терміну слугування; високий коефіцієнт витрати-ефективність. Виконаний аналіз методології RCM свідчить про його ефективність, що обумовлено більш низькою вартістю обслуговування виробничих активів за рахунок меншої кількості ре монтних робіт, при иьому зберігається надійність обладнання. Такий результат забезпечується створенням економічно вигідної ефективної стратегії та систематичного підходу для визначення програми поточного обслуговування. Доведено, що технічне обслуговування, яке спрямоване на забезпечення надійності, передбачає процес забезпечення виконання поставлених завдань в сучасному операційному контексті. При правильному застосуванні система RCM трансформує відносини між підприємствами, які ї̈ застосовують; наявними матеріальними фонда ми і персоналом, що експлуатують ці фонди $i$ забезпечує їх технічне обслуговування. Процес планування визначеної проблеми передбачає виконання наступних ключових елементів. визначення цілей та їх кількості; визначення обсягу і меж; оцінювання часу та кількість оглядів, необхідних для попереднього інспектування обладнання на кожній ділянці; формування плану реалізації рекомендацій. Крім того, ия система також забезпечує оперативне, ефективне $і$ чітке введення в експлуатацію нових виробничих фондів.

Ключові слова: технічне обслуговування, витрати, потенціал, розвиток, виробничі активи, вартість, ефективне управління, продуктивність праці, підприємство, ефективність.
ТЕОРЕТИКО-МЕТОДИЧЕСКИЕ АСПЕКТЫ

ОРГАНИЗАЦИИ ЭФФЕКТИВНОГО ТЕХНИЧЕСКОГО

ОБСЛУЖИВАНИЯ И РЕМОНТА

ПРОИЗВОДСТВЕННЫХ АКТИВОВ С ЦЕЛЬЮ

СНИЖЕНИЯ ЗАТРАТ И УВЕЛИЧЕНИЯ ПОТЕНЦИАЛА ПРЕДПРИЯТИЯ

\section{Шитикова Л.В., Ткаченко А.М., Войтенко С.В.}

Статья посвящена актуальной проблеме организации эффективного технического обслуживания и ремонтов производственных активов предприятий с целью сохранения их надежности и производительности, при обеспечении более низкой стоимости обслуживания за счет создания экономически выгодной стратегии и систематического подхода. В настояшее время проиесс изменений в промышленности получил еще большее развития. Стоимость технического обслуживания современных производственных активов, к сожалению, растет, как в абсолютном значении, так и в пропориии кобщим затратам. В работе доведено, что поскольку главной иелью развития предприятий является результативность хозяйственной деятельности, то повышение производительности труда при постоянном снижении затрат достигается обновлением и эффективным использованием современных технологий, техники, научных достижений в области организации эффективного технического обслуживания и ремонтов производственных машин и оборудования.Определены современные требования к техническому обслуживанию: более высокая степень готовности и надежности; большая степень безопасности; высокое качество продукции; экологическая безопасность; большая продолжительность срока службы; высокий коэффициент затраты-эффективность. Проведенный анализ методологии RCM свидетельствует о его эффективности, что обусловлено более низкой стоимостью обслуживания оборудования и робочих машин за счет меньшего числа ремонтных работ, при этом сохраняется их надежность. Такой результат обеспечивается созданием экономически выгодной эффективной стратегии и систематического подхода для определения программы текущего обслуживания. Доказано, что техническое обслуживание, направленное на обеспечение надежности, предусматривает процесс выполнения поставленных задач в современном операционном контексте. При правильном применении система RCM трансформирует отношения между предприятиями, которые ее применяют; имеющимися материальными фондами и персоналом, эксплуатирующими эти фонды и обеспечивает их техническое обслуживание.Процесс планирования задачи предусматривает выполнение следуюших ключевых элементов: определение целей и их количества; определение объема и границ; оценка времени и количество осмотров, необходимых для предварительного инспектирования оборудования на каждом участке; формирование плана реализации рекомендаций. Кроме того, эта система также обеспечивает оперативное, эффективное и четкое введение в эксплуатацию новых производственных фондов.

Ключевые слова: техническое обслуживание, затраты, потенциал, развитие, производственные активы, стоимость, эффективное управление, производительность труда, предприятие, эффективность. 


\section{THEORETICAL AND METHODOLOGICAL ASPECTS OF EFFECTIVE TECHNICAL MAINTENANCE AND REPAIR OF PRODUCTION ASSETS IN ORDER TO REDUCE COSTS AND INCREASE ENTERPRISE POTENTIAL}

Shitikova L.V. ", Tkachenko A.M., Voitenko S.V. Zaporizhzhia National Technical University, Zaporizhzhia

*e-mail: shris@mail.ru

The article is devoted to the actual problem of the effective maintenance organization and repair of production assets of enterprises in order to maintain their reliability and performance, while providing a lower cost of service by creating a cost-effective strategy and a systematic approach. Currently, the process of change in the industry has a larger development. The cost of maintenance of modern industrial assets is unfortunately increasing, both in absolute terms and in proportion to the overall costs. The paper informes that since the main purpose of the development of enterprises is the economic activity impact, the increase in labor productivity at constant cost reduction is achieved by updating and effective use of modern technology, technique, scientific advances in the field of effective maintenance and repair of industrial machinery and equipment. The current maintenance requirements are identified. They are: a high degree of availability and reliability; the greater degree of safety; high-quality products; environmental safety; longer life duration,; high rate of cost-effectiveness. The RCM methodology analysis demonstrates its effectiveness, due to the lower cost of equipment maintenance and working machines and due to fewer repairs, while maintaining their reliability. This result provides the cost-effective creation of the effective strategy and systematic approach to determine the current maintenance program. It is proved that the maintenance aimed at ensuring reliability provides the process for performing tasks in modern operational context. When applied correctly, RCM system transforms the relations between enterprises that use it; by the material funds and human resources, exploiting these assets and ensure their maintenance. The process of planning task involves the following key elements: the definition of objectives and their quantities; the determination of the extent and boundaries; assessing the time and number of inspections required for the preliminary inspection of the equipment at each site; plan to implement the recommendations. In addition, this system also ensures quick, efficient and accurate commissioning of new production assets.

Keywords: maintenance, costs, potential, development, production assets, cost effective management, productivity, enterprise efficiency.

\section{REFERENCES}

1. Antonenko T.A. (2014) Znyzhennja zatrat - odna z priorytetnyh strategij dijal'nosti pidpryjemstv / Zaporizhzhja: Tyzhden' nauky [in Ukrainian].

2. Mojsejenko V.I., Petrenko O.V., Chegodajev B.V. (2015) Vplyv tehnichnogo obslugovuvannja na pokaznyky RAMS [Bezvidmovnist', Gotovnist', Remontoprydatnist', Bezpeka] Zaliznychnyj transport Ukrai'ny [in Ukrainian].

3. Vlasjuk G.V. (2012) Teoretychni aspekty upravlinnja vytratamy vyrobnyctva na pidpryjemstvah u rynkovyh umovah. Derzhava ta regiony. Serija Ekonomika ta pidpryjemnyctvo. [in Ukrainian].

4. Kryvoruchko O. (2004) Systema upravlinnja jakistju tehnichnogo obslugovuvannja I remontu avtomobiliv. Standartyzacija, sertyfikacija, jakist'. [in Ukrainian].

5. Lytvyn O.O. (2011) Metodychni osnovy upravlinnja vytratamy na promyslovyh pidpryjemstvah Derzhava ta regiony. Serija: Ekonomika ta pidpryjemnyctvo. [in Ukrainian].

6. Mozgo V.A. (2005) Tehnycheskoe obsluzhyvanje: termynyyopredelenyja: [Tehnycheskoe obsluzhyvanje oborudovanyja] Metody menedzhmenta kachestva. [in Russian].

7. Perevozchykova N.A. (2004) Prymenenje systemnogo podhoda $v$ upravlenyy zatratamy na promyshlennyh predpryjatyjah Ukrayny. Donec'k: Donec'kyjnacional'nyj tehnichnyj universytet. Naukovi praci. Ser.: Ekonomichna. Vyp. 87. [in Russian].

8. Sholohov V. (2003) Tehnykavstyle «modern»: Promyshlennost' Ukrayny na chynaetvnedrjat' novejshje tehnologyy remonta. Den'gyytehnologyy. [in Russian]. 